\title{
COMPARISON OF MORPHOMETRIC CHARACTERS OF TWAITE SHAD (ALOSA FALLAX NILOTICA, GEOFFROY SAINT-HILAIRE, 1808) AMONG THREE AREAS IN TURKISH SEAS.
}

\author{
C. TURAN, N. BASUSTA
}

University of Mustafa Kemal, Faculty of Fisheries, 31040 ANTAKYA, Hatay, Turkey. Corresponding Author: Cemal TURAN

E-mail : cturan@mku.edu.tr

Fax : (90) 326-6427381

Tel : (90) 326-6427446

Reçu le 23 octobre 2000

Received 23 October, 2000

Accepté le 17 janvier 2001

Accepted 17 January, 2001

\section{ABSTRACT}

Degree of differentiation among populations of twaite shad, Alosa fallax nilotica, in Turkish territorial waters was evaluated with the truss morphometric system using Discriminant Function (DFA) and Principal Component Analyses (PCA). Approximately 40 individuals were collected from each sea to represent regions. In DFA, the proportion of correctly classified Eastern Mediterranean sea sample to their original group was highest $(90 \%)$ with a high overall random assignment of individuals into their original population (78\%). Plotting discriminant function 1 (DF1) and discriminant function 2 (DF2) explained $100 \%$ of total between group variability and clearly discriminated Eastern Mediterranean sea sample from the Baltic and Aegean sea samples, which were over plotted. This findings was also supported in multivariate analysis of variance. PCA revealed that the observed differences were mainly from posterior morphometric measurements of the fish. The patterns of morphological differentiation suggested that there is limited exchange of individuals among areas to homogenize populations phenotypically from the Black and Aegean seas to Eastern Mediterranean sea.

COMPARAISON DES CARACTÉRISTIQUES MORPHOLOGIQUES DE L'ALOSE FEINTE (MÉDITERRANÉE) (ALOSA FALLAX NILOTICA, GEOFFROY SAINT-HILAIRE, 1808) DANS TROIS AIRES GÉOGRAPHIQUES DES MERS TURQUES.

\section{RÉSUMÉ}

Le degré de différenciation entre les populations de l'alose feinte, Alosa fallax nilotica, dans les eaux territoriales turques a été évalué avec un système morphométrique renforcé basé sur les analyses de fonctions de discriminant (AFD) et les analyses de composants principal (ACP). Environ 40 individus furent capturés pour représenter chaque région. Avec les AFD, la proportion des individus bien classés provenant de la mer Méditerranée orientale par rapport à leur groupe d'origine était le plus élevé (90\%) avec une affectation importante totalement au hasard des individus dans la population d'origine (78\%). La représentation graphique de la fonction du discriminant 1 (DF1) et de la fonction du discriminant 2 (DF2) explique $100 \%$ de la variabilité totale entre 
groupes et montre clairement la différence entre les groupes de la mer Méditerranée Est et ceux de la mer Baltique et de la mer Egée, utilisés dans l'analyse. Les mêmes résultats ont été obtenus par l'analyse multivariée de la variance. L'ACP a révélé que les différences observées provenaient principalement des mesures morphologiques de la partie postérieure du poisson. Les différents patrons de différenciation morphologique observés suggèrent que les échanges d'individus entre les différentes zones marines sont limités ce qui a permis une homogénéisation phénotypique des populations depuis les mers Noire et Egée jusqu'à la Méditerranée orientale.

\section{INTRODUCTION}

The twaite shad Alosa fallax has a widespread distribution and ranges from Turkish coasts of the Black Sea (from Samsun) to throughout the Mediterranean sea and Northeast Atlantic coasts from northern Morocco to southern and western Iceland and Bergen ; North Sea, Baltic, Gulf of Bothnia and Gulf of Finland (FISCHER et al., 1987 ; WHITEHEAD, 1984). Twaite shad is represented by two subspecies: Alosa fallax fallax in Northeastern Atlantic area and Alosa fallax nilotica in Mediterraniean and Black Seas (WHITEHEAD, 1984 ; FISCHER et al., 1987 ; GELDIAY and BALIK, 1996). In Turkish seas, Alosa fallax nilotica rarely occur in Black and Aegean seas and commonly occur in Eastern Mediterranean sea. Alosa fallax nilotica have been mainly fished in the certain areas of each sea ; Sinop in the Black sea, Izmir in the Aegean sea and Iskenderun in the Eastern Mediterranean sea of Turkey. Populations of twaite shad are dominant in these regions. Because some of the biggest rivers in Turkey end out in these regions; the river of Sakarya ends out in Sinop, the river of Menderes ends out in Izmir, the rivers of Seyhan and Ceyhan end out in Iskenderun Bay.

A sustainable exploitation of Alosa fallax nilotica resources requires knowledge of stock structure in order to define appropriate management units or stocks (LAW and GREY, 1988 ; CARVALHO and HAUSER, 1994). Morphometric characters have been used in fisheries biology to measure discreteness and relationships among various taxonomic categories. There are numerous morphometric studies which provide evidence for stock discreteness (e.g. CORTI et al., 1988 ; VILLALUZ and MACCRIMMON, 1988 ; SHEPHERD, 1991 ; HADDON and WILLIS, 1995 ; BEMBO et al., 1996 ; TURAN, 1997).

The truss network system created by STRAUSS and BOOKSTEIN (1982) has been used increasingly for stock identification (WINANS, 1984 ; CORTI et al., 1988 ; SWAIN et al., 1991 ; ROBY et al., 1991 ; HAUSER et al., 1995 ; BEMBO et al., 1996 ; TURAN, 2000). The truss network system covers the entire fish in a uniform network, and increase the likelihood of extracting morphometric differences among populations.

There has been no any study on stock identification of twaite shad in Turkish waters.

Therefore in this study, it is aimed to elucidate population structure and differentiation of twaite shad populations among the Black, Aegean and Eastern Mediterranean seas.

\section{MATERIAL AND METHODS}

Samples were collected from the main fishing areas of the each sea from commercial catches in the Black (Sinop), Aegean (Izmir) and Eastern Mediterranean (Iskenderun) seas as a representative of each sea (Figure 1). Sampling locations, sampling gear, sample size and standard length of samples are depicted in Table I. No sex was recorded from the samples. 


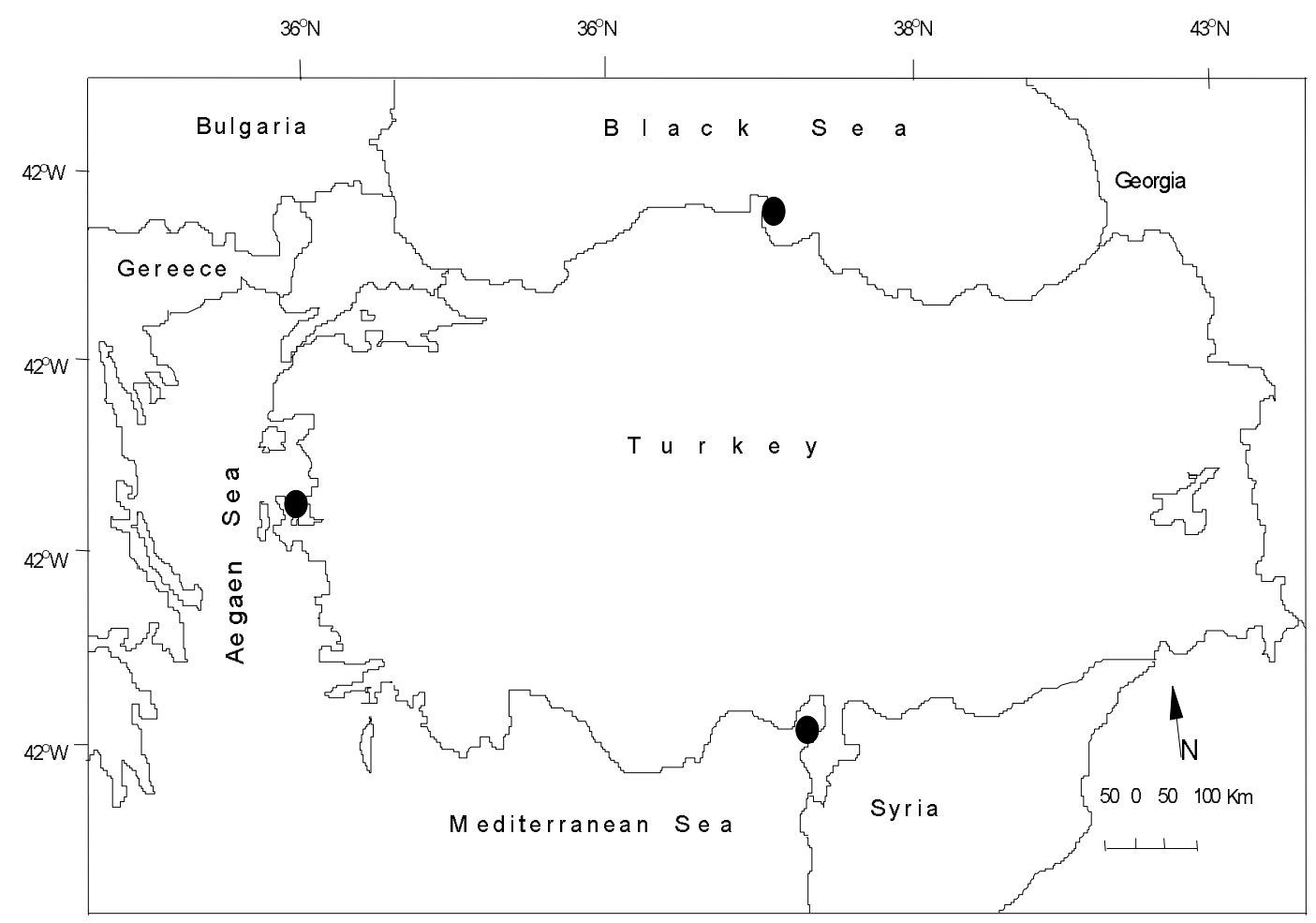

Figure 1

Localization of Twaite shad (Alosa fallax). Sampling (•).

Figure 1

Localisation des points (zones) d'échantillonnage $(\bullet)$ de l'alose feinte (Alosa fallax).

\section{Table I}

Location, sampling technique, and biological features of twaite shad (Alosa fallax). Standard deviations of mean standard length (STL) of samples are given in brackets.

\section{Tableau I}

Emplacement, méthode d'échantillonnage, caractéristiques biologiques de l'alose feinte (Alosa fallax). Les écarts standards de la longueur moyenne des échantillons sont reportés entre parenthèses.

\begin{tabular}{|c|c|c|c|c|c|}
\hline Sample & Locations & $\begin{array}{c}\text { Collection } \\
\text { Time }\end{array}$ & Gear & $\begin{array}{c}\text { Sample } \\
\text { size }\end{array}$ & $\begin{array}{c}\text { Mean STL (cm) } \\
( \pm \text { SD) }\end{array}$ \\
\hline Black sea (BS) & $35^{\circ} 15^{\prime} \mathrm{N} 41^{\circ} 75^{\prime} \mathrm{E}$ & 05.11 .1999 & Gill net & 39 & $27.3( \pm 1.66)$ \\
\hline Aegean sea (AS) & $26^{\circ} 85^{\prime} \mathrm{N} 38^{\circ} 35^{\prime} \mathrm{E}$ & 22.10 .1999 & Gill net & 48 & $15,8( \pm 1.76)$ \\
\hline E-Mediterranean (EM) & $36^{\circ} 05^{\prime} \mathrm{N} 36^{\circ} 65^{\prime} \mathrm{E}$ & 12.11 .1999 & Gill net & 41 & $18.3( \pm 1.13)$ \\
\hline
\end{tabular}


A fish was laid out on a polystyrene board, 20 points were pinned for digitizing, and viewed under a camera with a monitor. Measurement TV was used to provide shape measurements. The co-ordinates of each measurements were recorded to the nearest $0.1 \mathrm{~mm}$, and the distance between two points was measured to within $0.1 \mathrm{~mm}$. The raw data for the 149 fish measured were examined for outliers that could indicate errors or damaged specimens, and to compare the size distributions of the samples. Outliers were excluded from the future analysis. The 21 fish identified as outliers were excluded form the future analyses, thus providing the final number of 128 fish.

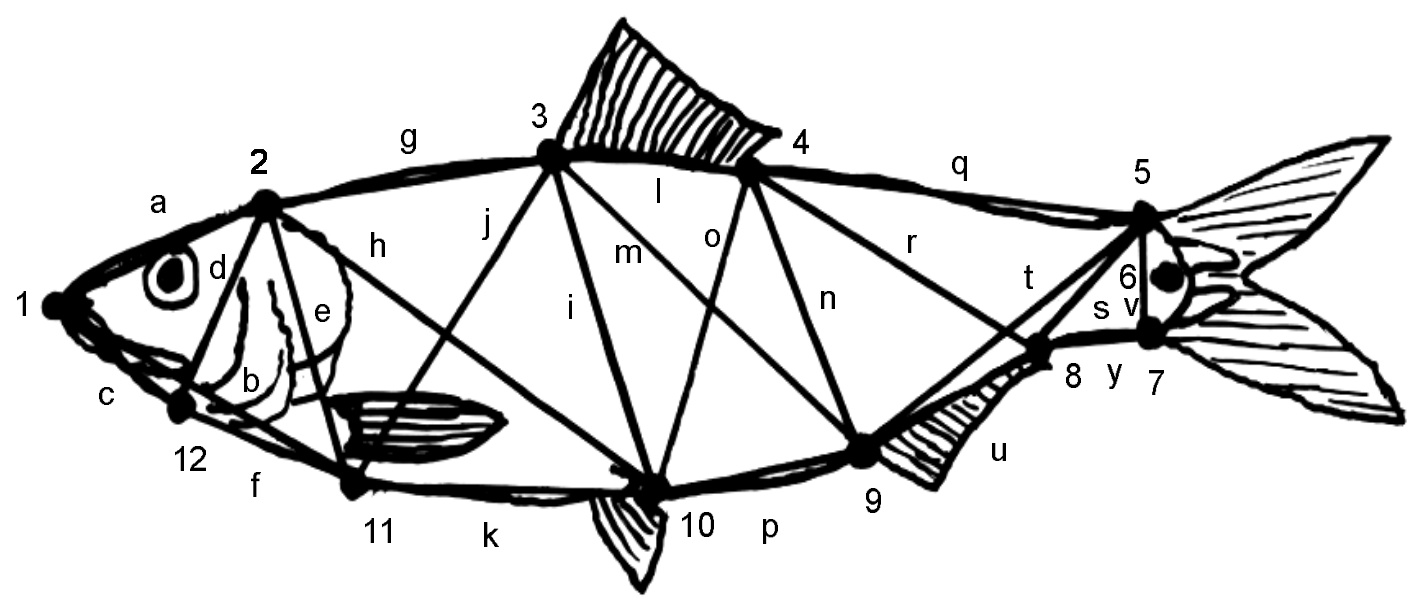

Figure 2

Locations of the 12 landmarks for constructing the truss network on fish (๑) and morphometric lengths between dots (arabic letters). Landmarks refer to (1) anterior tip of snout at upper jaw, (2) most posterior aspect of neurocranium (beginning of scaled nape), (3) origin of dorsal fin, (4) insertion of dorsal fin, (5) anterior attachment of dorsal membrane from caudal fin, (6) posterior end of vertebrae column, (7) anterior attachment of ventral membrane from caudal fin, (8) insertion of anal fin, (9) origin of anal fin, (10) insertion of pelvic fin, (11) insertion of pectoral fin, (12) posteriomost point of maxillary.

\section{Figure 2}

Les emplacements des 12 points de repères de mesures en réseau (•) sur le poisson et les longueurs morphométriques mesurées entre ces points noirs (lettre arabes). Les points de repère sont (1) l'extrémité antérieure du nez à la mâchoire supérieure, (2) l'aspect le plus postérieur du neurocrane (début de la nuque écaillée), (3) origine de la nageoire dorsale, (4) insertion de la nageoire dorsale, (5) point d'attache antérieur de la membrane dorsale de la nageoire caudale, (6) partie terminale postérieure de la colonne vertébrale, (7) point d'attache antérieur de la membrane ventrale de la nageoire caudale, (8) insertion de la nageoire anale, (10) insertion de la nageoire pelvienne, (11) insertion de la nageoire pectorale, (12) point le plus postérieur du maxillaire.

Multivariate techniques were used to exhibit pattern of differentiation among samples that simultaneously consider the variation in several characters and thereby assess the morphometric similarities between samples. Principal component analysis (PCA) requires no a priori grouping of individuals but combines and summarizes the variation associated with each of a number of measured variables into a smaller number of principal components (PC) which are a linear combination of the variables that describe 
the shape variations in the pooled sample. Principal component analysis was used to remove size effect from the shape measures (SOMERS, 1986). This method extracts a first component as isometric size factor, allowing the subsequent components to be interpreted as summarizing shape variation independent of size and random variation among the sampled individuals. The subsequent principal components were used in discriminant function analysis (DFA). Discriminant function analysis combines a selection of body measures in a linear fashion to produce a mathematical function which can be used to separate or classify individuals into groups. The percentage of correctly classified individuals gives a measure of the morphological distinctness of the samples.

Univariate analysis of variance (ANOVA) was used to compare the variation among samples for truss measurements. The number of significantly different measurements among groups was an additional indication of the degree of group separation. Multivariate analysis of variance (MANOVA) was performed to test the significance of differences among the samples in the data set.

\section{RESULTS}

In principal component analysis (PCA), 25 principal components (PCs) which contains percentage of total variance of all variables were produced and $88 \%$ of the total variation was presented in first PC which presents allometrik size factor and was excluded from the analyses. The subsequent components (24 PCs) represented $12 \%$ of the variation which were used in discriminant function analysis (DFA).

In DFA, the overall random assignment of individuals into their original population was high $(78 \%)$ (Table II). The proportion of correctly classified Eastern Mediterranean sea sample to their original group was highest $(90 \%)$, showing a clear separation from the other samples.

\section{Table II}

Underlined bold numbers in the diagonal are the percentage of individuals classified correctly into their original group. Below the diagonal, results of multivariate analyses of morphometric variability in twaite shad (Alosa fallax). Significance levels of pairwise multivariate comparisons between samples (MANOVA) are presented above the diagonal $\left(^{* \star *}=\mathrm{P}<0.001 ; \mathrm{ns}=\right.$ not significant).

\section{Tableau II}

Les nombres soulignés en caractères gras dans la diagonale correspondent aux pourcentages des individus bien classés dans leur groupe d'origine. En dessous de la diagonale, sont reportés les résultats des analyses multivariées de la variabilité morphométrique de l'alose feinte (Alosa fallax). Les niveaux de signification des comparaisons multivariées par paire d'échantillons sont présentés au dessus de la diagonale $\left(^{\star \star \star}=\mathrm{P}<0.001 ; \mathrm{ns}=\right.$ non significatif).

\begin{tabular}{|c|c|c|c|}
\hline Samples & Aegean sea & Black sea & E-Mediterranean \\
\hline Aegean sea & $\underline{\mathbf{7 9} \%}$ & & \\
\hline Black sea & $\mathrm{ns}$ & $\underline{67 \%}$ & \\
\hline E-Mediterranean & $* \star *$ & $* * *$ & $\underline{90 \%}$ \\
\hline
\end{tabular}


In DFA, two discriminant functions (DFs) were produced, and plotting DF1 and DF2 explained $100 \%$ of total between group variability. The first DF accounted for $98 \%$, and the second accounted for $2 \%$ of the between-group variability (Figure 3). The Eastern Mediterranean sea sample was clearly separated from the Baltic and Aegean sea samples, which were over plotted.

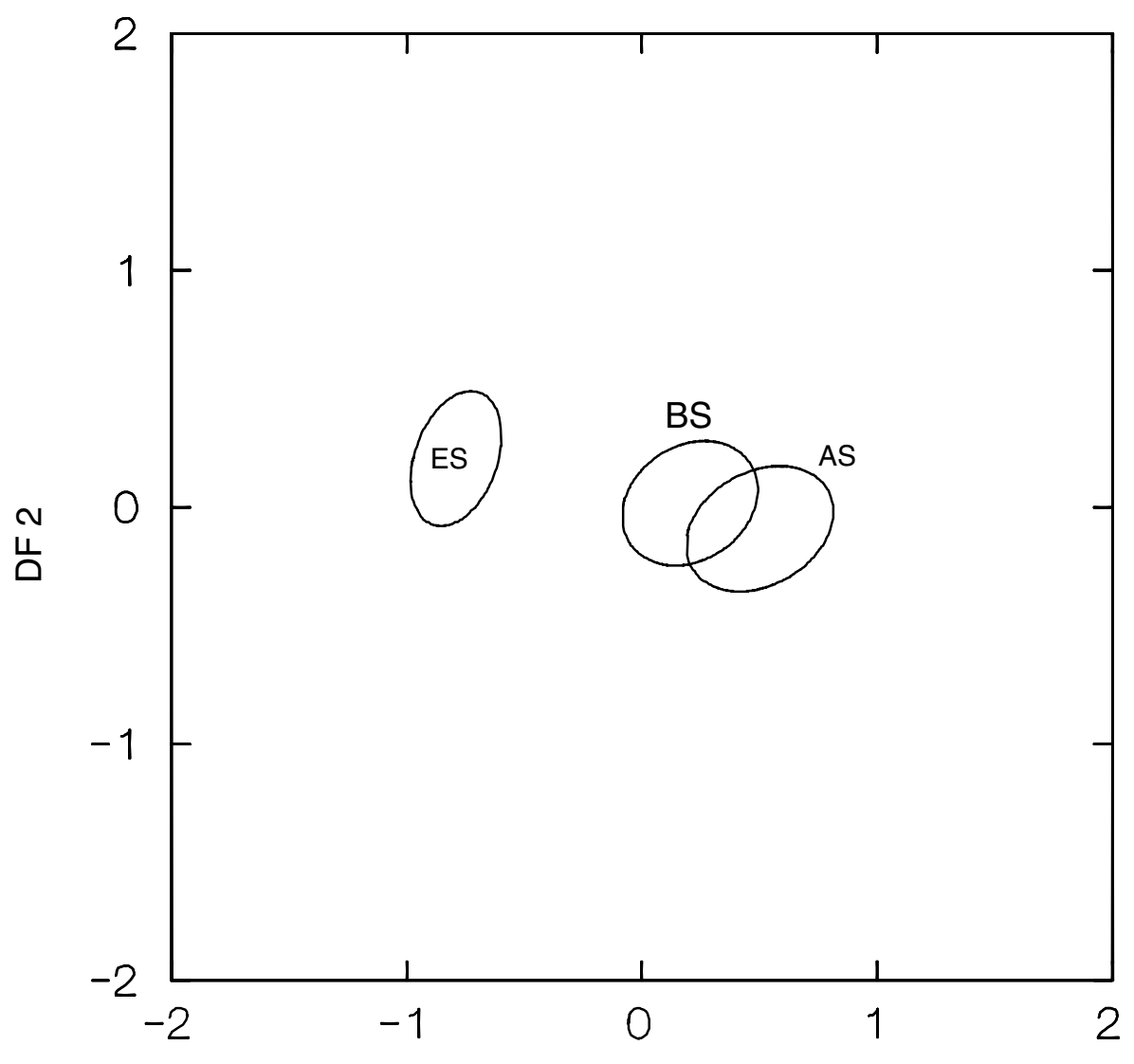

\section{DF 1}

Figure 3

Sample centroids and $95 \%$ confidence ellipses of discriminant function scores. Samples referred to in the text were Black sea (BS), Aegean sea (AS), Estern Mediterranean (EM). The first discriminant function (DF1) accounts for $98 \%$, and second (DF2) accounts for $2 \%$ of the between group variability.

\section{Figure 3}

Centre de gravité des échantillons et ellipses des intervalles de confiance à $95 \%$ des valeurs des fonctions discriminantes. Les échantillons en références dans le texte sont de la Mer Noire (BS), la Mer Egée (AS), de l'Est de la Méditerranée (EM). La première fonction discriminante (DF) compte pour $90 \%$ de la variabilité entre groupe et la seconde (DF2) pour $2 \%$.

Univariate statistics (ANOVA) revealed highly significant $(P<0.001)$ differences between the three samples from all truss measurements. Pairwise comparisons using a multivariate ANOVA (MANOVA) (Table II) revealed that only the Eastern Mediterranean sea sample was highly significant $(P<0.001)$ from the Baltic and Aegean sea samples, however the Baltic and Aegean sea samples were not significant from each other. 
In order to illustrate which morphometric characters differentiate populations, pooled within-groups correlations between discriminating variables and discriminant functions were produced with DFA. This revealed that the observed differences were mainly from posterior morphometric measurements and from body depth measurements (i, j, h, n, d) of the fish (Table III).

\section{Table III}

Pooled within-groups correlations between discriminating variables and standardized canonical discriminant functions. Variables ordered by level of correlation within function. *, denotes largest correlation between each variable and discriminant functions. Locations of the arabic letters on fish for the truss network is illustrated at Figure 2.

\section{Tableau III}

Corrélations à l'intérieur des groupes entre les variables discriminantes et les fonctions discriminantes canoniques standardisées. Les variables sont rangées par valeur croissante de corrélation dans la fonction. *, indique les plus hauts coefficients de corrélation entre la variable et les fonctions discriminantes. Les lettres arabes indiquent l'emplacement des mesures en réseau faites sur le poisson en Figure 2.

\begin{tabular}{|c|c|c|}
\hline \multirow[b]{2}{*}{ Variables } & \multicolumn{2}{|c|}{ Function } \\
\hline & 1 & 2 \\
\hline 1 & $0,652^{*}$ & 0,262 \\
\hline $\mathrm{J}$ & $0,587^{*}$ & 0,172 \\
\hline $\mathrm{H}$ & $0,569^{*}$ & 0,281 \\
\hline $\mathrm{N}$ & $0,525^{\star}$ & 0,295 \\
\hline $\mathrm{R}$ & $0,515^{*}$ & 0,194 \\
\hline$C$ & $0,511^{*}$ & 0,292 \\
\hline$E$ & $0,481^{*}$ & 0,039 \\
\hline $\mathrm{V}$ & $0,474^{*}$ & $-0,015$ \\
\hline$U$ & $0,470^{*}$ & 0,166 \\
\hline 0 & $0,467^{*}$ & 0,409 \\
\hline $\mathrm{K}$ & $0,435^{\star}$ & 0,183 \\
\hline $\mathrm{L}$ & $0,419^{*}$ & 0,272 \\
\hline$Q$ & $0,417^{*}$ & 0,364 \\
\hline$Y$ & $0,408^{*}$ & 0,332 \\
\hline$F$ & $0,404^{*}$ & 0,337 \\
\hline$T$ & $0,398^{*}$ & 0,199 \\
\hline $\mathrm{D}$ & $0,374^{*}$ & 0,357 \\
\hline $\mathrm{HD}$ & $0,349^{*}$ & 0,081 \\
\hline$S$ & $0,348^{*}$ & 0,275 \\
\hline$B$ & $0,318^{*}$ & 0,203 \\
\hline$A$ & $0,311^{*}$ & 0,201 \\
\hline$E Y$ & 0,363 & $0,485^{\star}$ \\
\hline$M$ & 0,382 & $0,481^{*}$ \\
\hline$G$ & 0,294 & $0,465^{*}$ \\
\hline$P$ & 0,287 & $0,357^{*}$ \\
\hline
\end{tabular}




\section{DISCUSSION}

The present morphometric study exhibited evidence of highly significant morphometric heterogeneity of Eastern Mediterranean twaite shad with an high proportion of individuals being classified into their correct a priori grouping. The result of DFA and MANOVA suggests that there is a low level of intermingling of twaite shad from Eastern Mediterranean to the Baltic and Aegean sea which create morphological differentiation of Eastern Mediterranean twaite shad. There has been no study on morphological differentiation of twaite shad in Turkish waters to compare our findings.

Principal component analysis indicated that morphometric differentiation between samples was largely located in the posterior region of twaite shad, and from body depth measurements. The inter-population variation in body depth measurements may be attributed to swimming ability. TAYLOR and MCPHAIL (1985) found morphological differences between salmon populations from inland and coastal rivers. Two forms were classified ; a coastal form, with deep robust bodies, and an inland form, with shallower and more streamlined bodies. The characterization of the groups was related to possible differences in adaptations to swimming (migrants) for prolonged periods. Inland populations, must cope with long and energetically demanding migrations, thus selection should favour a more fusiform body shape that minimizes energy expenditure (TAYLOR and MCPHAIL, 1985). On the other hand, morphometric differences might reflect different adjustments by fish to their feeding environment, prey types and availability or other features associated with pre- or post settlement of fish. Some environmental factors such as temperature, salinity, food availability or prolonged swimming may, for example, determine the potential phenotypic discreteness of herring. Therefore the localized variation detected here may be attributable to possible morphological adaptation of stocks to food or migratory swimming.

This study produced evidence of differences in body shape between twaite shad caught on the Eastern Mediterranean and others caught on the Aegean and Black seas. However biological significance of these phenotypic distinction, and their possible implication for management of the twaite shad fishery, are not clear. Such differences suggest that in some way fish in Eastern Mediterranean is a different stock, and fish in the Aegean and Black sea are the member of same stock. If the phenotypic differences detected are not accidental, then it should be repeatable in the further samples which require a test of continuity. Therefore further studies are needed to demonstrate temporal stability of morphometric discreteness of twaite shad in Eastern Mediterranean.

\section{BIBLIOGRAPHY}

BEMBO D.G., CARVALHO G.R., CINGOLANI N., ARNERI E., GIANETTI G., PITCHER T.J., 1996. Allozymic and morphometric evidence for two stocks of the European anchovy, Engraulis encrasicolus, in Adriatic waters. Mar. Biol., 126, 529-538.

CARVALHO G.R., HAUSER L., 1994. Molecular genetics and the stock concept in fisheries. Rev. Fish Biol. Fisher., 4, 326-350.

CORTI M., THORPE R.S., SOLA L., SBORDONI V., CATAUDELLA S., 1988. Multivariate morphometrics in aquaculture : a case study of six stocks of the common carp (Cyprinus carpio) from Italy. Can. J. Fish. Aquat. Sci., 45, 1548-1554.

FISCHER W., SCHNEIDER M., BAUCHOT M.L., 1987. Fiches FAO d'identification des espèces pour les besoins de la pêche. (Révision 1). Méditerranée et mer Noire. Zone de pêche 37. Volume II. Vertébrés. Publication Préparée par la FAO et la Commission des Communautés Européennes (Projet GCP/INT/422/EEC) financée conjointement par ces deux organisations. FAO, Rome, 761-1530.

GELDIAY R., BALIK S., 1994. Türkiye Tatlisu Baliklari. Ege Üniversitesi Su Ürünleri Fakültesi Yainlari, No 46, Dizin No 16. 210-217. 
HADDON M., WILLIS T.J. 1995. Morphometric and meristic comparison of Orange Roughy (Hoplostethus atlanticus, Trachichthyidae) from the Puysegur Bank and Lord-HoweRise, New-Zealand, and Its implications for stock structure. Mar. Biol., 123, $19-27$.

HAUSER L., CARVALHO G.R., PITCHER T.J., 1995. Morphological and genetic differentiation of the African clupeid Limnothrissa miodon 34 years after its introduction to Lake Kivu. J. Fish Biol., 47 (Suppl. A), 127-144.

LAW R., GREY D.R., 1988. Maximum sustainable yields and the self renewal of exploited populations with age-dependent vital rates, 140-156. In : EBENMAN B. and PERSSON L. (Eds.) Size structured populations : ecology and evolution. SpringerVerlag, Berlin and Heidelberg.

SHEPHERD G., 1991. Meristic and morphometric variation in Black Sea Bass North of Cape hatteras, North Carolina. Am. J. Fish. Man., 11, 139-149.

STRAUSS R.E., BOOKSTEIN F.L., 1982. The truss : body form reconstruction in morphometrics. Syst. Zool., 31, 113-135.

SWAIN D.P., RIDELL B.E., MURRAY C.B., 1991. Morphological differences between hatchery and wild populations of coho salmon (Oncorhynchus kisutch) : environment versus genetic origin. Can. J. Fish. Aquat. Sci., 48, 1783-1791.

TAYLOR E.B., MCPHAIL J.D., 1985. Variation in body morphology among British Columbia populations of coho salmon, Oncorhynchus kisutch. Can. J. Fish. Aquat. Sci., 42, 2020-2028.

TURAN C., 1997. Population Structure of Atlantic herring, Clupea harengus L., in the Northeast Atlantic using Phenotypic and Molecular Approaches, PhD. Thesis, The University of Hull, Hull, U.K.

TURAN C., 2000. Otolith Shape and Meristic Analysis of Herring (Clupea harengus) in the Northeast Atlantic. Archive of Fishery and Marine Research., 48 (3), 283-295.

VILLALUZ A.C., MACCRIMMON H.R., 1988. Meristic variations in milkfish, Chanos chanos, from Philippine waters. Mar. Biol., 97, 145-150.

WHITEHEAD P.J.P., 1984. Clupeidae. In : WHITEHEAD P.J.P., BAUCHOT M.L., HUREAU J.C., NIELSEN J. and TORTONESE E. (Eds.). Fishes of the Northeastern Atlantic and the Mediterranean, Vol. 1. UNESCO, Paris, 268-281.

WINANS G.A., 1984. Multivariate Morphometric Variability in Pacific Salmon - Technical Demonstration. Can. J. Fish. Aquat. Sci., 41, 1150-1159. 
